\title{
Analisa Hubungan Lingkungan, APD dan Pengalaman Kerja Terhadap Kecelakaan Kerja pada Fabrikasi Konstruksi Baja Proyek Pabrik Kelapa Sawit
}

\author{
Fahmi Firdaus Alrizal**1, Siti Choiriyah², Rahmad Andri Ifandi ${ }^{3}$ \\ ${ }^{1,2,3}$ Program Studi Teknik Sipil, FTSP, ITATS. Surabaya \\ Email: ${ }^{1}$ fahmi.alrizal@itats.ac.id
}

Received 10 Februari 2020; Reviewed 22 April 2020; Accepted 27 Mei 2020

Journal Homepage: http://jurnal.borneo.ac.id/index.php/borneoengineering

\begin{abstract}
Occupational safety and health are very important instruments in the process of steel construction work, especially in fabrication. In the construction of oil palm mills with steel construction for fabrication items that are often the possibility to work accidents, so there is no need for one work item that can get an exemption, both in the process of cutting, moving, welding, and the packaging process of steel material used. PT Boma Bisma Indra (Persero) in the palm oil mill (CPO) steel construction fabrication project. This research was conducted with a non-probability sampling method and conducted with regression. Based on the results of the study can be known about the influence of Environmental variables, personal protective equipment (PPE), and the experience of workers on work accidents.
\end{abstract}

Keywords: Environmental variables, personal protective equipment (PPE), the experienced worker, work accident

\begin{abstract}
Abstrak
Keselamatan dan kesehatan kerja merupakan suatu instrument yang sangat penting dalam kegiatan proses pekerjaan konstruksi baja khususnya pada fabrikasi. Dalam pembangunan pabrik kelapa sawit dengan konstruksi baja untuk item fabrikasi sering terdapat kemungkinan terjadinya kecelakaan kerja, sehingga tidak ada satu item pekerjaan yang dapat memperoleh pengecualian, baik itu didalam proses pemotongan, pemindahan, proses pengelasan maupun proses packing material baja yang digunakan. Penelitian ini bertujuan untuk menganalisis pengaruh hubungan lingkungan, alat pelindung diri (APD) dan pengalaman pekerja terhadap kecelakaan kerja karyawan PT Boma Bisma Indra (persero) pada proyek fabrikasi konstruksi baja pabrik kelapa sawit (CPO). Penelitian ini dilakukan dengan metode non probability sampling dan dianalisis dengan regresi. Berdasarkan hasil penelitian dapat diketahui bahwa adanya pengaruh variabel lingkungan, alat pelindung diri (APD) dan pengalaman pekerja terhadap kecelakaan kerja.
\end{abstract}

Kata kunci : Lingkungan kerja, alat pelindung diri (APD), pengalaman kerja, kecelakaan kerja

\section{Pendahuluan}

Kesehatan dan Keselamatan kerja dalam konstruksi menjadi faktor yang harus diperhatikan dalam dunia konstruksi agar tidak terjadi kecelakaan pada pelaksanaannya, khususnya dalam pekerjaan yang menggunakan alat berat yaitu konstruksi baja. Kecelakaan kerja didalam pekerjaan fabrikasi 
konstruksi baja sering timbul karena keterkaitan beberapa faktor, diantaranya adalah faktor teknis yang menjadi hal yang paling utama dalam penggunaan alat kerja yang tidak sesuai standar serta faktor lingkungan yang memungkinkan pekerja yang bekerja di tempat sempit atau di ketinggian serta meremehkan didalam proses pemindahan material. Dengan banyaknya item proses kegiatan pada pekerjaan fabrikasi konstruksi baja, maka harus banyak yang perlu diperhatikan dalam melaksanakan pekerjaan fabrikasi konstruksi baja tersebut.

Lingkungan kerja, APD (alat pelindung diri) dan pengalaman kerja sangat berperan terhadap kecelakaan kerja, karena kecelakaan kerja tidaklah terjadi begitu saja. Kelalaian perusahaan yang memusatkan diri pada keuntungan semata dan kegagalan pemerintah mensosialisasikan program akan pentingnya $\mathrm{K} 3$ merupakan dua penyebab besar kematian/kecelakaan terhadap pekerja.

Kecelakaan kerja adalah suatu kejadian yang tidak dikehendaki dan tidak diduga semula yang dapat menimbulkan kerugian dalam materill dan non materiil (Tarwaka, 2014). sedangkan Permenaker PP/No.50/2012 tentang keselamatan kerja, kecelakaan kerja adalah suatu kejadian yang tidak diduga semula dan tidak dikehendaki, yang mengacaukan proses yang telah diatur dari suatu aktivitas dan dapat menimbulkan kerugian baik korban manusia maupun harta benda.

perilaku tenaga kerja dan lingkungan kerja yang dimoderasi faktor pengalaman kerja dan tingkat pendidikan terhadap kecelakaan kerja konstruksi hanya mencari pengaruh variabel lingkungan kerja yang dimoderasi faktor pengalaman kerja dan tingkat pendidikan terhadap kecelakaan kerja konstruksi. (Faris dan Harianto, 2014). Menurut Junior dan Vasconcelos (2015) dan Bavafa dkk (2018) Penentuan pekerja sebagai subjek pelaksana dalam proyek merupakan hal utama untuk mengidentifikasi faktor-faktor dalam pengaruh pekerja terhadap kecelakaan kerja. Sehingga kcelakaan dapat diidentifikasi dahulu untuk meningkatkan produktivitas dalam proyek khususnya dalam hal kesehatan dan keselamatan kerja. (Busyairi dkk, 2014) dan (Cheng dkk, 2010). Pada penelitian ini akan ditambahkan variabel alat pelindung diri (APD) dengan 4 indikator pada proyek fabrikasi konstruksi baja. Oleh karenaitu pada penelitian ini bertujuan mengetahui pengaruh lingkungan kerja, alat pelindung diri (APD) dan pengalaman kerja terhadap kecelakaan kerja pada fabrikasi konstruksi baja proyek pabrik kelapa sawit (CPO) khususnya pelaksana dalam proyek.

\section{Metode Penelitian}

Penelitian diawali dengan menggunakan kuisioner. Kuesioner merupakan cara pengumpulan data dengan memberikan pertanyaan - pertanyaan pada beberapa sampel yang dipilih menggunakan rumus slovin Sugiyono (2011). Berdasarkan persamaan 1, Sampel yang diambil pada penelitian ini adalah tenaga kerja yaitu fitter, welder dan helper yang bersentuhan langsung pada proyek fabrikasi konstruksi baja pembangunan pabrik kelapa sawit (CPO) di PT Boma Bisma Indra (persero) yang berjumlah total 40 orang.

$$
n=\frac{N}{1+N e^{2}}
$$

Keterangan :

n : ukuran sampel

$\mathrm{N} \quad$ : ukuran populasi

e : persen kelonggaran ketidaktelitian karean kesalahan pengambilan sampel yang masih dapat ditolerir atau diinginkan, $10 \%$

Berdasarkan pada penelitian terdahulu dan referensi-referensi yang terkait dalam penelitian ini. maka perlu dilakukan penelitian hubungan antara variabel independen $(\mathrm{X})$ terhadap variabel dependen (Y), yang dapat dilihat pada Gambar 1. 


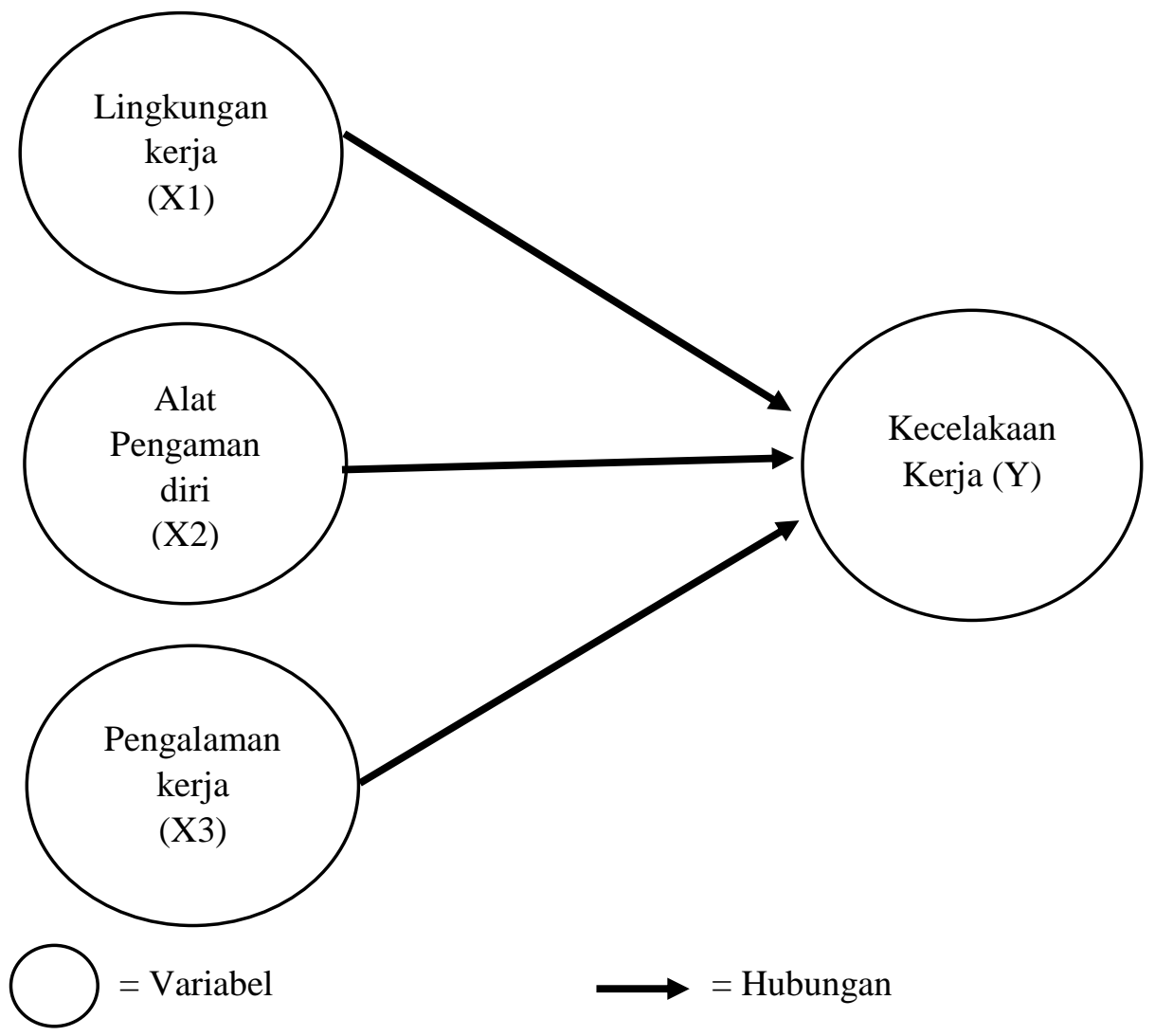

Gambar 1. Kerangka Konsep Penelitian

Dari gambar 1, terdapat empat variabel dengan 3 variabel independen (X) dan 1 Variabel dependen (Y). Variabel tersebut akan dianalisa apakah variabel independen mempengaruhi variabel dependen khususnya dalam pekerjaan fabrikasi konstruksi baja yang lebih jelasnya dapat dilihat pada tabel 1 . Penelitian ini dianalisa menggunakan Analisa Statistik karena pengujian suatu penelitian sangat tergantung pada data yang digunakan dalam pengujian.

Tabel 1. Variabel dan Indikator Penelitian

\begin{tabular}{lll}
\hline \multicolumn{1}{c}{ Variabel Penelitian } & \multicolumn{1}{c}{ Indikator } & Code \\
\hline Lingkungan Kerja (X1) & 1. Komunikasi antar pekerja & $\mathrm{X} 1-1$ \\
& 2. Keamanan lingkungan & $\mathrm{X} 1-2$ \\
& 3. Posisi alat kerja & $\mathrm{X} 1-3$ \\
& 4. Lahan kerja yang sempit & $\mathrm{X} 1-4$ \\
\hline Alat Pelindung Diri (X2) & 1. Kualitas Peralatan & $\mathrm{X} 2-1$ \\
& 2. Helm & $\mathrm{X} 2-2$ \\
& 3. Sepatu & $\mathrm{X} 2-3$ \\
& 4. Tali safety & $\mathrm{X} 2-4$ \\
\hline Pengalaman kerja (X3) & 1. Masa kerja $\leq 5$ tahun & $\mathrm{X} 3-1$ \\
& 2. Masa kerja $\geq 5$ tahun & $\mathrm{X} 3-2$ \\
\hline Kecelakaan Kerja (Y) & 1. Terpukul benda keras & $\mathrm{Y}-1$ \\
& 2. Tertimpa benda jatuh & $\mathrm{Y}-2$ \\
& 3. Patah tulang & $\mathrm{Y}-3$ \\
& 4. Luka pada tangan & $\mathrm{Y}-4$ \\
& 5. Luka pada badan & $\mathrm{Y}-5$ \\
\hline
\end{tabular}

Sumber: Faris dan Harianto (2014), Transiska dkk. (2015), Hola dkk. (2017), Nawawinetu (2018) Yuamita dan Waruwu (2016), ismail dkk (2012) dan Karimi dan taghaddos (2019) 
Setelah data dikumpulkan, dilakukan pengolahan data agar data mudah dimanfaatkan dalam analisis oleh alat bantu analisis dalam menjawab tujuan dari penelitian. Data kemudian akan diolah lebih lanjut menggunakan uji validitas, uji reliabilitas, uji normalitas, uji korelasi dan uji analisa regresi berganda dengan program bantu SPSS.

Uji validitas adalah suatu pengujian yang dilakukan agar kuesioner yang dipakai untuk mengukur variabel penelitian valid atau tidak, dilanjutkan dengan uji reliabilitas untuk mengetahui hasil konsistensi data. Dilanjutkan uji normalitas data yang menjadi persyaratan utama dalam analisis parametrik, karena data yang dianalisa harus memiliki berdistribusi normal. Kemudian dilanjutkan pengujian regresi linier berganda yang bertujuan untuk menganalisis seberapa besar pengaruh variabel independen terhadap variabel dependen.

\subsection{Uji Validitas}

Setelah semua nilai korelasi untuk tiap - tiap pertanyaan dengan skor total diperoleh, nilai - nilai tersebut dibandingkan nilai kritik tabel. Variabel yang ditanyakan dapat digunakan adalah variabel dengan angka kritik diatas angka signifikan 5\%. Dasar pengambilan keputusan jika $r$ hasil $>\mathrm{r}$ tabel maka butir atau variabel tersebut valid. Untuk perumusan dasarnya dapat dilihat pada persamaan 2.

$$
\mathrm{R} \text { hitung }=\frac{N\left(\sum(i x)-\left(\sum i\right)(x)\right)}{\sqrt{\left[\left(N \sum i^{2}\right)-\left(\sum i^{2}\right)\left[\left(N \sum x^{2}\right)-\left(\sum x^{2}\right)\right]\right]}}
$$

Dimana :

$\mathrm{R}_{\mathrm{ix}} \quad$ : koefisien korelasi item-total (bivariate pearson)

i : skor item

$\mathrm{x} \quad$ : skor total

n : banyaknya subjek

\subsection{Uji Reabilitas}

Instrumen penelitian baik apabila data tersebut valid namun juga harus reliable (dapat dipercaya) artinya ketepatan yang mana bila diujikan pada kelompok yang sama dalam waktu yang berbeda akan menghasilkan nilai yang sama pula. Perhitungan reliabilitas instrument dilakukan dengan menggunakan program bantu SPSS.

Dari hasil uji coba angket tersebut dilakukan pembahasan untuk mendapatkan butir - butir angket yang valid dan reliable berdasarkan aturan di atas, untuk butir item angket yang tidak valid di drop. Sehingga angket yang digunakan untuk penelitian adalah angket yang sudah valid dan reliable berdasarkan hasil uji coba. Koefisien korelasi realibity dapat dilihat pada persamaan 3 .

$$
\mathrm{R} \text { tot }:\left(\frac{k}{k-1}\right)\left(1-\frac{\sum \sigma b^{2}}{\sigma 1^{2}}\right)
$$

Dimana :

Rtot $=$ reliabilitas instrument

$\mathrm{K}$ = banyaknya butir pertanyaan

$\sum b^{2}=$ jumlah varians butir

$\sigma 2 t=$ Varians total 
Untuk pengolahan hasil kuesioner awal dilakukan dengan uji validitas dan reabilitas. Adapun langkah-langkah yang dilakukan adalah membuat tabel awal dengan menyusun skor jawaban pertanyaan masing-masing responden. Pada masalah ini tabulasi terutama untuk mengetahui distribusi variabel-variabel.

\subsection{Uji Normalitas Data}

Untuk uji normalitas bertujuan untuk menguji apakah dalam model regresi, variabel pengganggu atau residual memiliki distribusi normal. Uji statistik yang digunakan dalam penelitian ini adalah uji statistik non parametric Kolmogorov - Smirnov Test (K-S). Jika nilai p-value >0.05, maka data dinyatakan berdistribusi normal Ghozali (2013).

\subsection{Uji Korelasi}

Uji korelasi merupakan uji suatu perangkat uji yang diperlukan untuk mengetahui bentuk hubungan yang terjadi diantara variabel yang sedang diteliti. Uji korelasi merupakan uji untuk melihat apakah ada hubungan linear yang signifikan dari tiap variabel yang sedang diteliti. Kriteria dari (Riduwan, 2003) menggambarkan harga $r$ akan dikonsultasikan dengan Tabel interpretasi Nilai $r$ dapat dilihat pada tabel 2 .

\begin{tabular}{ll}
\multicolumn{2}{l}{ Tabel 2. Interprestasi Koefisien Korelasi Nilai r } \\
\hline Koefisien Korelasi Nilai r & Tingkat Hubungan \\
\hline $0,80-1,000$ & Sangat Kuat \\
$0,60-0,799$ & Kuat \\
$0,40-0,599$ & Cukup Kuat \\
$0,20-0,399$ & Rendah \\
$0,00-0,199$ & Sangat Rendah \\
\hline
\end{tabular}

Sumber : Riduwan dan Akdon (2013)

\subsection{Uji Regresi Linier Berganda}

Regresi linear berganda bertujuan untuk menganalisis nilai pengaruh beberapa variabel bebas atau independent terhadap variabel terikat. Dilakukan penyebaran kuisioner dan kemudian, dalam perhitungan digunakan program bantu SPSS.

\subsection{Uji Parsial T (Uji T)}

Uji T dilakukan dengan program bantu SPSS untuk mengetahui apakah secara individu (parsial) variabel independen mempengaruhi variabel independen secara signifikan atau tidak yang dapat dilihat pada persamaan 4 .

$$
\text { T hitung }: \frac{\sqrt{r n-2}}{\sqrt{1-r^{2}}}
$$

dimana :

$\mathrm{r} \quad$ : koefisien korelasi hasil $\mathrm{r}$ hitung

$\mathrm{n} \quad$ : jumlah responden 
membandingkan nilai $t$ hitung dengan $\mathrm{t}$ table, jika $\mathrm{t}$ hitung $>\mathrm{t}$ tabel maka valid dan jika $\mathrm{t}$ hitung $<\mathrm{t}$ tabel maka tidak valid

\subsection{Uji Serempak (Uji F)}

Langkah - langkah pengujian dengan menggunakan Uji F adalah sebagai berikut:

1. Menentukan Tingkat Signifikan sebesar $\alpha=5 \%$

Tingkat signifikansi 0.05 atau $5 \%$ artinya kemungkinan besar hasil penarikan kesimpulan memiliki probabilitas $95 \%$ atau toleransi kesalahan $5 \%$

2. Menghitung Uji F (F-test)

Perhitungan uji $\mathrm{F}$ dapat dilihat pada persamaan 5.

$$
F_{\text {hitung }}=\frac{R^{2} / k}{\left(1-R^{2}\right) /(n-k-1)}
$$

Dimana,

$\mathrm{R}^{2} \quad=$ koefisien determinasi gabungan

$\mathrm{n} \quad=$ jumlah sampel

$\mathrm{k} \quad=$ jumlah variabel independen

\section{Hasil dan Pembahasan}

Responden penelitian yang dipakai adalah tenaga kerja yaitu fitter, welder dan helper yang bersentuhan langsung pada proyek fabrikasi konstruksi baja pembangunan pabrik kelapa sawit dan dikarenakan populasi pekerja/responden yang ada di proyek ini sangat banyak serta dikarenakan keterbatasan waktu, biaya, dan tenaga, serta mengacu dari Sugiyono (2011), bahwa ukuran minimum sampel yang dapat diterima pada desain penelitian deskriptif adalah $10 \%$ dari populasi sedangkan untuk populasi relatif kecil minimal 20\% dari populasi, pendapat dan persepsi seseorang maupun kelompok tentang kejadian atau gejala sosial yang ada. Sehingga 30 Sampel digunakan dalam penelitian ini.

$$
n=\frac{40}{1+40(0,1)^{2}}=30 \text { Sampel }
$$

Untuk analisis dan pembuktian hipotesis ini penulis menggunakan bantuan program bantu SPSS. Hal ini dilakukan dengan pertimbangkan bahwa hasil pengolahan dan perhitungan data yang dihasilkan akan lebih cepat dilakukan yang akan menghemat waktu serta memiliki tingkat keakuratan yang lebih baik.

\subsection{Uji Validitas}

Setelah hasil dari nilai korelasi untuk tiap-tiap pertanyaan dengan skor total diperoleh, nilai-nilai tersebut dibandingkan nilai kritik tabel. Nilai dari indikator digunakan adalah hasil kuisioner dengan angka kritis diatas angka signifikan 5\%. Dasar pengambilan keputusan jika $r_{\text {hitung }}>r_{\text {tabel }}$ maka butir atau variabel tersebut valid. Hasil pengujian validitas dari indikator-indikator tiap variabel dalam penelitian dapat dilihat pada Tabel 3. 
Tabel 3. Hasil Uji Validitas

\begin{tabular}{clccc}
\hline $\begin{array}{c}\text { Variabel } \\
\text { Penelitian }\end{array}$ & \multicolumn{1}{c}{ Indikator } & $\mathbf{R}_{\text {HITUNG }}$ & $\mathbf{R}_{\text {TABEL }}$ & Keterangan \\
\hline Lingkungan & 1. Komunikasi antar pekerja & 0,803 & 0,3610 & Valid \\
Kerja (X1) & 2. Keamanan lingkungan & 0,639 & 0,3610 & Valid \\
& 3. Posisi alat kerja & 0,705 & 0,3610 & Valid \\
& 4. Lahan kerja yang sempit & 0,443 & 0,3610 & Valid \\
\hline Alat Pelindung & 1. Kualitas Peralatan & 0,531 & 0,3610 & Valid \\
Diri (X2) & 2. Helm & 0,443 & 0,3610 & Valid \\
& 3. Sepatu & 0,535 & 0,3610 & Valid \\
& 4. Tali safety & 0,842 & 0,3610 & Valid \\
\hline Pengalaman & 1. Masa kerja $\leq 5$ tahun & 0,535 & 0,3610 & Valid \\
kerja (X3) & 2. Masa kerja $\geq 5$ tahun & 0,455 & 0,3610 & Valid \\
\hline Kecelakaan & 1. Tertimpa benda jatuh & 0,639 & 0,3610 & Valid \\
Kerja (Y) & 2. Patah tulang & 0,386 & 0,3610 & Valid \\
& 3. Luka pada tangan & 0,397 & 0,3610 & Valid \\
& 4. Luka pada badan & 0,443 & 0,3610 & Valid \\
\hline
\end{tabular}

Berdasarkan hasil uji validitas pada tabel 2, dapat dilihat bahwa semua indikator yang digunakan utnuk mengukur masing-masing variabel telah valid sebab nilai $r_{\text {hitung }}>r_{\text {tabel }}(0,3610)$. Hal ini menunjukkan bahwa semua item pertanyaan terbukti valid sehingga item dapat digunakan untuk penelitian.

\subsection{Uji Reabilitas}

data penelitian yang baik harus valid namun juga harus reliabel (dapat dipercaya) artinya ketepatan yang mana bila diujikan pada kelompok yang sama dalam waktu yang berbeda akan menghasilkan nilai yang sama pula. Untuk mengukur reliabilitas digunakan nilai Cronbach Alpha (rhitung). Jika nilai Cronbach Alpha $>\mathrm{r}$ tabel dangan $\mathrm{r}_{\text {tabel }}=0.361$, maka variabel penelitian dikatakan reliabel/valid. Berikut adalah hasil pengujian reliabilitas dari variabel dalam penelitian pada tabel 4 .

Tabel 4. Hasil Uji Reliabilitas

\begin{tabular}{lcl}
\hline \multicolumn{1}{c}{ Variabel } & $\begin{array}{c}\text { Cronbach } \\
\text { Alpha }\end{array}$ & Keterangan \\
\hline Lingkungan kerja (X1) & 0,801 & Reliabel / Valid \\
APD (X2) & 0,636 & Reliabel / Valid \\
Pengalaman Kerja (X3) & 0,539 & Reliabel / Valid \\
Kecelakaan kerja (Y) & 0,739 & Reliabel / Valid \\
\hline
\end{tabular}

Berdasarkan tabel 3, dapat diketahui bahwa besarnya Cronbach Alpha pada keempat variabel lebih besar dari $\mathrm{r}_{\text {tabel }}$, dengan jumlah data $(\mathrm{n})=30$, maka didapatkan nilai rtabel sebesar 0.361 , sehingga dapat disimpulkan bahwa item atau butir tersebut reliabel atau bisa disebut data bisa dipercaya.

\subsection{Uji Normalitas}

Hasil output dari uji normalitas menggunakan Kolomogorov-Smirnov dapat dilihat pada tabel 5.

Berdasarkan uji normalitas dengan metode Kolmogorov - Smirnov pada Tabel 5 dapat disimpulkan bahwa data berdistribusi normal. Hal ini dapat diketahui dengan melihat nilai Kolmogorov Smirnov sebesar 0,828 dengan tingkat signifikan sebesar 0,499. Jika signifikan nilai KolmogorovSmirnov 0,499>0,05, maka dapat dinyatakan bahwa data mempunyai distribusi normal. 
Tabel 5. Hasil Uji Normalitas

\begin{tabular}{llr}
\hline & & \multicolumn{2}{c}{$\begin{array}{c}\text { Unstandardized } \\
\text { Predicted Value }\end{array}$} \\
\hline $\mathrm{N}$ & & 30 \\
Normal Parameters & & $3 . \mathrm{b}$ \\
& Mean & 15.8000000 \\
Most Extreme Differences & Std. Deviation & 1.31320651 \\
& Absolute & .151 \\
& Positive & .151 \\
Kolmogorov-Smirnov Z & Negative & -.114 \\
Asymp. Sig. (2-tailed) & & .828 \\
\hline
\end{tabular}

\subsection{Uji Korelasi}

Uji korelasi merupakan angka yang menujukkan arah dan kuatnya hubungan antar dua variabel atau lebih. Arah dinyatakannya dalam bentuk hubungan positif atau negatif, sedangakan kuatnya hubungan dinyatakan dalam besarnya koefisien korelasi (Sugiyono, 2011). Analisa korelasi merupakan bagian dari penerapan statistika yang yang digunakan untuk mengetahui keeratan atau derajat kekuatan hubungan linier dari suatu variabel dengan variabel lain. Hasil uji korelasi dapat dilihat pada tabel 6 .

Tabel 6. Hasil Uji Korelasi (Correlations)

\begin{tabular}{llrrrr}
\hline & $\begin{array}{c}\text { Kecelakaan } \\
\text { Kerja }\end{array}$ & $\begin{array}{c}\text { Lingkungan } \\
\text { Kerja }\end{array}$ & $\begin{array}{c}\text { Alat Pelindung } \\
\text { Diri (APD) }\end{array}$ & $\begin{array}{c}\text { Pengalaman } \\
\text { Kerja }\end{array}$ \\
\hline \multirow{3}{*}{$\begin{array}{l}\text { Pearson } \\
\text { Correlation }\end{array}$} & Lecelakaan Kerja & 1,000 &, 324 &, 408 &,- 100 \\
& Alat Pelindung Diri &, 524 & 1,000 &, 655 &, 250 \\
& (APD) &, 408 &, 655 & 1,000 &, 386 \\
& Pengalaman Kerja &, 479 &, 250 &, 386 & 1,000 \\
& Kecelakaan Kerja &, &, 040 &, 013 &, 300 \\
Sig. (1-tailed) & Lingkungan Kerja &, 040 &, 000 &, 091 \\
& Alat Pelindung Diri &, 013 &, 000 &, 017 &, 017 \\
& (APD) &, 021 &, 091 & 30 & 30 \\
& Pengalaman Kerja & 30 & 30 & 30 & 30 \\
& Kecelakaan Kerja & 30 & 30 & 30 & 30 \\
& Lingkungan Kerja & 30 & 30 & 30 & 30 \\
\hline
\end{tabular}

Berdasarkan tabel 6 didapatkan bahwa nilai signifikansi lingkungan kerja terhadap kecelakaan kerja $0,040<0,05$ sehingga ada pengaruh yang signifikan, jika dilihat dari nilai koefisien korelasinya 0,524 artinya hubungannya cukup kuat. Sedangkan nilai signifikansi alat pengaman diri (APD) terhadap kecelakaan kerja 0,013 <0,05 sehingga ada hubungan yang signifikan, dan jika dilihat dari nilai koefisien korelasinya 0,408 artinya hubungannya cukup kuat. Untuk variabel independen terakhir yaitu pengalaman kerja terhadap kecelakaan kerja $0,021<0,05$ sehingga ada pengaruh yang signifikan, bila dilihat dari nilai koefisien korelasinya 0,479 artinya hubungannya cukup kuat. Dapat disimpulkan bahwa berdasarkan tabel 2, maka 3 variabel independen terhadap variabel dependennya memiliki korelasi dan variabel lingkungan, alat pengaman diri dan pengalaman dalam bekerja berpengaruh terhadap kecelakaan kerja. 


\subsection{Analisa Regresi Berganda}

Setelah diketahui apakah variabel independen (X) memiliki pengaruh terhadap variabel dependen (Y), dilanjutkan dengan analisa regresi linear berganda yang bertujuan untuk menganalisis nilai pengaruh beberapa variabel bebas atau independent terhadap variabel terikat. Berdasarkan analisis dengan program bantu statistik didapatkan hasil regresi linier berganda seperti pada tabel 7.

Tabel 7. Hasil Analisis Regresi Linear Berganda

\begin{tabular}{lcc}
\hline \multicolumn{1}{c}{ Variabel } & Koefisien Regresi & Standart Error \\
\hline Konstanta & 7,165 & 2,562 \\
Lingkungan Kerja (X1) & $-0,054$ & 0,180 \\
Alat Pengaman Diri (APD) (X2) & 0,714 & 0,232 \\
Pengalaman Kerja (X3) & $-0,248$ & 0,316 \\
\hline
\end{tabular}

Berdasarkan hasil analisis pada tabel 7 didapatkan persamaan regresi dalam penelitian ini dapat dilihat pada persamaan 6 .

$$
Y=7,165-0,054 X_{1}+0,714 X_{2}-0,248 X_{3}+e
$$

Berdasarkan persamaan 6 maka memiliki makna sebagai berikut:

1. Nilai konstanta sebesar 7,165 berarti jika variabel lingkungan kerja, APD dan pengalaman kerja dianggap sama dengan nol, maka variabel kecelakaan kerja sebesar 7,165 satuan.

2. Nilai koefisien regresi untuk variabel lingkungan kerja (X1) adalah sebesar - 0,054 artinya setiap penambahan 1 unit konstanta variabel lingkungan kerja maka akan menyebabkan penurunan kecelakaan kerja sebesar 0,054. Artinya apabila lingkungan pekerja semakin tinggi kecelakaan kerja juga akan semakin rendah.

3. Nilai koefisien regresi untuk variabel APD (X2) adalah sebesar 0,714 artinya setiap penambahan 1 unit konstanta variabel APD maka akan menyebabkan kenaikan kecelakaan kerja sebesar 0,714. Artiya apabila ada kelalaian penggunaan APD maka kecelakaan kerja akan semakin tinggi.

4. Nilai koefisien regresi untuk variabel pengalaman kerja (X3) adalah sebesar - 0,248 artinya setiap penambahan 1 unit konstanta variabel pengalaman kerja maka akan menyebabkan penurunan kecelakaan kerja sebesar 0,248. Artinya apabila pengalaman kerja semakin tinggi kecelakaan kerja juga akan semakin rendah.

\subsection{Uji Parsial T}

Uji $\mathrm{T}$ dilakukan untuk mengetahui apakah secara individu (parsial) variabel independen mempengaruhi variabel dependen secara signifikan atau tidak. Hasil output dari program bantu dapat dilihat pada Tabel 8.

Berdasarkan hasil pengujian statistik pada tabel 8 menunjukan bahwa variabel lingkungan kerja (X1) diperoleh nilai $\mathrm{t}_{\text {hitung }}=-0,299<\mathrm{t}_{\text {tabel }}=2,059$ dengan nilai signifikansi $=0,767>0,05 ; \mathrm{H} 0$ diterima. Jadi secara parsial tidak ada pengaruh signifikan antara lingkungan kerja (X1) terhadap kecelakaan kerja (Y) di fabrikasi konstruksi baja studi kasus pada fabrikasi konstruksi baja pembangunan pabrik kelapa sawit (CPO) di PT Boma Bisma Indra (persero). Hal tersebut sesuai dengan yang dikemukakan oleh Transiska dkk. (2015), Hola dkk. (2017) dan Nawawinetu (2018) bahwa lingkungan kerja sangat mempengaruhi terhadap kecelakaan kerja. Pada variabel alat pelindung diri (X2) diperoleh nilai $t_{\text {hitung }}=3,076>t_{\text {tabel }}=2,059$ dengan nilai signifikansi $=0,005<$ 0,05 H1diterima. Jadi secara parsial ada pengaruh signifikan antara APD terhadap kecelakaan kerja 
(Y) di fabrikasi konstruksi baja studi kasus pada fabrikasi konstruksi baja pembangunan pabrik kelapa sawit (CPO) di PT Boma Bisma Indra (persero). Hal tersebut sesuai dengan yang dikemukakan oleh Yuamita dan Waruwu (2016), ismail dkk (2012) dan Hola dkk.(2017) bahwa faktor alat pengaman diri (APD) mempengaruhi kecelakaan kerja. Sedangkan wijaya dan agushinta (2016) mengemukakan kecelakaan terhadap APD sangat berkaitan dengan kesehatan dan keselamatan kerja (K3). Dan variabel terakhir yaitu pada pengalaman kerja (X3) diperoleh nilai $\mathrm{t}_{\text {hitung }}=-0,785<\mathrm{t}_{\text {tabel }}=2,059$ dengan nilai signifikansi $=0,440>0,05 ;$ Ho diterima. Jadi secara parsial tidak ada pengaruh signifikan antara pengalaman kerja (X3) terhadap kecelakaan kerja (Y) di fabrikasi konstruksi baja studi kasus pada fabrikasi konstruksi baja pembangunan pabrik kelapa sawit (CPO) di PT Boma Bisma Indra (persero) dikarenakan tidak adanya kecelakaan pada proyek karena mayoritas responden bekerja lebih dari 5 tahun. Sehingga hal tersebut seperti diungkapkan oleh Yunartha dan Nita (2016) serta Karimi dan taghaddos (2019) semakin lama pengalaman kerja maka semakin sedikit kecelakaan yang terjadi.

Tabel 8. Hasil Perhitungan Uji Parsial

\begin{tabular}{llrrrrr}
\hline \multirow{2}{*}{ Model } & \multicolumn{2}{c}{$\begin{array}{c}\text { Unstandardized } \\
\text { Coefficients }\end{array}$} & $\begin{array}{c}\text { Standardized } \\
\text { Coefficients }\end{array}$ & t & Sig. \\
\cline { 2 - 7 } & \multicolumn{1}{c}{ B } & Std. Error & \multicolumn{1}{c}{ Beta } & & \\
\hline 1 & (Constant) & 7.165 & 2.562 & & 2.797 & .010 \\
& Lingkungan Kerja & -.054 & .180 & -.075 & -.299 & .767 \\
& APD & .714 & .232 & .786 & 3.076 & .005 \\
Pengalaman Kerja & -.248 & .316 & -.147 & -.785 & .440 \\
\hline
\end{tabular}

Keterangan : a. Dependent Variable: Kecelakaan Kerja

\subsection{Uji Serempak F}

Uji F dilakukan untuk mengetahui apakah semua variabel independen secara simultan berpengaruh terhadap variabel dependen. Berikut adalah hasil pengujian dari hasil perhitungan penelitian dapat dilihat pada Tabel 9.

Tabel 9. Hasil Uji F ( Tabel Anova)

\begin{tabular}{llrrrrc}
\hline Model & & Sum of Squares & \multicolumn{1}{c}{ df } & Mean Square & F & Sig. \\
\hline 1 & Regression & 50.011 & 3 & 16.670 & 6.489 & $.002^{\mathrm{a}}$ \\
& Residual & 66.789 & 26 & 2.569 & & \\
& Total & 116.800 & 29 & & & \\
\hline
\end{tabular}

Keterangan :

a. Predictors: (Constant), Pengalaman Kerja, Lingkungan Kerja, APD

b. Dependent Variable: Kecelakaan Kerja

Pada Tabel 9 diperoleh nilai $\mathrm{F}_{\text {hitung }}=6,498>\mathrm{F}_{\text {tabel }}=2,975$ dengan nilai sigfinikansi $=0,002<0,05$ maka $\mathrm{H}_{0}$ ditolak dan $\mathrm{H}_{1}$ diterima yang berarti variabel bebas atau independen (faktor: $\mathrm{X} 1, \mathrm{X} 2, \mathrm{X} 3$ ) secara bersama - sama berpengaruh terhadap variabel tergantung atau dependen (Y). Maka dengan kata lain variabel-variabel independen lingkungan, alat pengaman diri (APD) dan pengalaman kerja, mampu menjelaskan besarnya variabel dependen kecelakaan kerja. Hal tersebut sesuai dengan yang dikemukakan oleh Feng dkk (2015) bahwa faktor-faktor tersebut mempengaruhi kecelakaan kerja dan Variabel tersebut merupakan dalam sistem keselamatan kerja yang akan berpengaruh terhadap kecelakaan kerja sesuai yang diungkapkan oleh Yiu dkk (2016), dan mohammadi dkk (2018) 


\section{Kesimpulan}

Berdasarkan hasil penelitian yang telah dilakukan pada tenaga kerja di fabrikasi konstruksi baja proyek pabrik kelapa sawit (CPO) di PT Boma Bisma Indra (persero), dapat ditarik kesimpulan bahwa dari hasil analisis regresi dan analisa variabel diketahui adanya pengaruh lingkungan, alat pengaman diri (APD), dan pengalaman pekerja terhadap kecelakaan kerja. Indikator lingkungan kerja berpengaruh terhadap kecelakaan kerja, semakin baik komunikasi antar pekerja, keamanan lingkungan kerja, posisi alat kerja, dan tempat lahan kerja yang sesuai standar K3 (misalnya : lahan area kerja yang tidak sempit, tingkat kebisingan, pecahayaan dan adanya rambu-rambu K3) maka akan mengurangi resiko kecelakaan kerja. Indikator alat pengaman diri (APD) juga berpengaruh terhadap kecelakaan kerja. Apabila kualitas peralatan baik dan semua pekerja sudah memakai APD, maka resiko kecelakaan kerja akan menurun. Pengalaman kerja merupakan variabel yang juga menentukan kecelakaan kerja, semakin tinggi pengalaman kerjanya (masa pengalaman kerja yang lebih dari 5 tahun) maka resiko kecelakaan kerja akan lebih kecil.

Berdasarkan dari uji-uji yang telah dilakukan ( Uji F / uji serempak, Uji T / uji parsial , uji korelasi). Oleh karena itu, jika variabel X (lingkungan kerja, APD, dan pengalaman kerja) dalam kondisi baik, ditambah masa pengalaman kerja $\geq 5$ tahun mempengaruhi kejadian kecelakaan kerja pada fabrikasi konstruksi baja proyek pabrik kelapa sawit di PT Boma Bisma Indra (persero) tidak pernah terjadi.

\section{Daftar Pustaka}

Bavafa, A., Mahdiyar, A., dan Marsono, A. K.,. 2018. Identifying and assessing the critical factors for effective implementation of safety programs in construction projects. Safety Science Vol.106. Hal. 47-56. ISSN: 1879-1042

Busyairi, M., Tosungku, L.O.A.S., dan Oktaviani, A.,. 2014. Pengaruh Keselamatan Kerja dan Kesehatan Kerja terhadap Produktivitas Kerja Karyawan. Jurnal Ilmiah Teknik Industri, Vol. 13, No. 2, Desember 2014. Hal. 113-124. ISSN 1412-6869

Faris, I.A., dan Harianto F., 2014. Pengaruh Perilaku Tenaga Kerja dan Lingkungan yang Dimoderasi Faktor Pengalaman Kerja dan Tingkat Pendidikan Terhadap Kecelakaan Kerja Konstruksi di Surabaya. Jurnal Teknik Sipil Institut Adhi Tama Surabaya, hal 57-63. ISBN 978-979-99327-9-2

Feng, Y., Zhang, S., dan Wu, P., 2015. Factors influencing workplace accident costs of building projects. Safety Science. Vol. 72. Hal. 97-104. ISSN: 1879-1042

Cheng, C.W., Leu, S.S., Lin, C.C., dan Fan, C., 2010. Characteristic analysis of occupational accidents at small construction enterprises. Safety Science.Vol. 48 No.6, 698-707.

Ghozali, Imam. 2013. Aplikasi Analisis Multivariate dengan Program IBM SPSS 21 Update PLS Regresi. Semarang: Badan Penerbit Universitas Diponegoro. Hal. 155 - 165.

Hoła. B., Nowobilskia. T., Szerb. I., dan Szerb, J., 2017. "Identification of factors affecting the accident rate in the construction industry" dalam proceeding 2nd International Workshop on flexibility in sustainable construction, ORSDCE 2017, (Poland, 24-26 April 2017) 
Ismail, Z., Doostdar, S., dan Harun, Z.,. 2012. Factors influencing the implementation of a safety management system for construction sites. Safety Science., vol. 50 No.3. Hal. 418-423. ISSN: $1879-1042$

Junior, B. B., dan Vasconcelos, B.,. 2015. "The causes of work place accidents and their relation to construction equipment design" dalam 6th International Conference on Applied Human Factors and Ergonomics (AHFE 2015) and the Affiliated Conferences, AHFE 2015, (Amerika, 26-30 Juli 2015)

Karimi, H., dan Taghaddos, K.,. 2019. The influence of craft workers' educational attainment and experience level in fatal injuries prevention in construction projects. Safety Science Vol.119. Hal. 417-427. ISSN: 1879-1042

Mohammadi, A., Tavakolan, M., dan Khosravi, Y.,. 2018. Factors influencing safety performance on construction projects: A review. Safety Science., vol. 109 No.3. Hal. 382-397. ISSN: $1879-1042$

Nawawinetu. E.D., dan Akmalia. R.R., 2018. Hubungan Karakteristik Pekerja dan Lingkungan Kerja dengan Kejadian Kecelakaan Kerja di Pt Waskita Karya (Persero). Journal of Industrial Hygiene and Occupational Health Vol. 3, No. 1, Oktober 2018. Hal 1-12. ISSN: 2541-5727

Nita dan Yunartha, M.,. 2016. Hubungan Pengalaman Kerja Dan Kelelahan Dengan Kecelakaan Kerja Di Bagian Operasional Pt. Energi Mega Persada (Emp) Gelam Muaro Jambi Tahun 2016. Scintia Journal Vol.5 No.2. Desember 2016. Hal. 206-211. ISSN: 2528-0082

Presiden Republik Indonesia. 2012. Peraturan Pemerintah Republik Indonesia Nomor 50 Tahun 2012 Tentang Penerapan Sistem Manajemen Keselamatan dan Kesehatan Kerja (PP No.50/2012). Jakarta

Riduwan dan Akdon, 2013. Rumusan Dan Data Dalam Analisis Statistik, Bandung: Alfabeta, Hal 80-90

Sugiyono, 2011, Statistika Untuk Penelitian, Bandung: Alfabeta, Hal 80-231.

Tarwaka, 2014, Manajemen dan Implementasi K3 di Tempat Kerja, Surakarta: Harapan Press, hal $10-23$.

Transiska. D., Nuryanti., Taufiqurrahman, 2015. Pengaruh Lingkungan Kerja Dan Faktor Manusia Terhadap Tingkat Kecelakaan Kerja Karyawan Pada PT. Putri Midai Bangkinang Kabupaten Kampar. Jom Fekon Vol 2 No. 1 Februari 2015. Hal 1-15. ISSN : 1963-6590

Wijaya, R.A.K., dan Agushinta L.,. 2016. Pengaruh Penerapan Kesehatan dan Keselamatan Kerja terhadap Kecelakaan Kerja Karyawan. Jurnal Manajemen Bisnis Transportasi dan Logistik, Vol. 2 No.2 Januari 2016. Hal. 287-295. ISSN: 2356-5519

Yiu., N. S. N., Chan, D. W. M., Shan, M dan Sze, N.N.,. 2019. Implementation of safety management system in managing construction projects: Benefits and obstacles. Safety Science., vol. 117. Hal.23-32 ISSN: 1879-1042

Yuamita, F., dan Waruwu, S.,. 2016. Analisis Faktor Kesehatan Dan Keselamatan Kerja (K3) yang Signifikan Mempengaruhi Kecelakaan Kerja pada Proyek Pembangunan Apartement Student Castle. Spektrum Industri. Vol. 14, No. 1, Hal.63-78. ISSN : 1963-6590 